\title{
Effects of land-cover and watershed protection futures on sustainable groundwater management in a heavily utilized aquifer in Hawai'i (USA)
}

\author{
Leah L. Bremer ${ }^{1,2}$ (D) Ahmed S. Elshall ${ }^{2,3} \cdot$ Christopher A. Wada $^{1,2} \cdot$ Laura Brewington $^{4} \cdot$ Jade M.S. Delevaux ${ }^{5} \cdot$ \\ Aly I. El-Kadi ${ }^{2,6} \cdot$ Clifford I. Voss $^{2} \cdot$ Kimberly M. Burnett ${ }^{1,2}$
}

Received: 11 August 2020 / Accepted: 20 January 2021 / Published online: 21 April 2021

(C) The Author(s) 2021

\begin{abstract}
Groundwater sustainability initiatives, including sustainable yield and watershed policy protection policies, are growing globally in response to increasing demand for groundwater, coupled with concerns about the effects of climate and land-cover change on groundwater supply. Improved understanding of the impacts of watershed management on groundwater yields and management costs - particularly in the broader context of climate and land-cover change - is critical to inform these initiatives and facilitate integrated land and water management. This study develops a novel, spatially explicit groundwater hydrologic ecosystem services framework, which combines stakeholder-defined land-cover scenarios, sustainable yield estimation using a groundwater simulation optimization approach, and economic valuation, and applies it in the most heavily utilized aquifer Hawai' $i$ (USA). Sustainable yield estimates and resulting differences in replacement costs are estimated for six land-cover scenarios (with varying levels of urban development and watershed management) crossed with two water demand scenarios in a context of a dry future climate (Representative Concentration Pathway [RCP] 8.5 mid-century). Land-cover change is found to be an important, though less significant drive of changes in groundwater recharge than climate change. The degree of watershed protection, through preventing the spread of high-water-use, invasive plant species, is projected to be a much stronger land-cover signal than urban development. Specifically, full forest protection increases sustainable yield by 7-11\% (30-45 million liters per day) and substantially decreases treatment costs compared with no forest protection. Collectively, this study demonstrates the hydrologic and economic value of watershed protection in a context of a dry future climate, providing insights for integrated land and water policy and management in Hawai'i and other regions, particularly where species invasions threaten source watersheds.
\end{abstract}

Keywords Groundwater management · Water supply $\cdot$ Hydrologic ecosystem services $\cdot$ Watershed management $\cdot$ Sustainable yield $\cdot$ Invasive species

Leah L. Bremer

lbremer@hawaii.edu

Ahmed S. Elshall

aelshall@hawaii.edu

1 University of Hawai‘i Economic Research Organization, Honolulu, HI, USA

2 Water Resources Research Center, University of Hawai' ${ }^{\circ}$, Honolulu, HI, USA

3 Department of Earth, Ocean, and Atmospheric Science, Florida State University, Tallahassee, FL, USA

4 East-West Center, Honolulu, HI, USA

5 The Natural Capital Project, Stanford University, Stanford, CA, USA

6 Department of Earth Sciences, University of Hawai' $i$, Honolulu, HI, USA

\section{Introduction}

Planning for water security in a context of global environmental change is one of the most pressing challenges worldwide (Taylor et al. 2013; Wheater and Gober 2015; Elshall et al. 2020; Gleeson et al. 2020). Groundwater is an essential component of water security, supplying nearly half of drinking and irrigation water globally (Cross et al. 2016; Giordano 2009). Demand for groundwater has led to drastic overextraction in many regions, causing salinization of freshwater wells, land subsidence, and degradation of groundwater dependent ecosystems (Narasimhan 2009; Moosdorf and Oehler 2017; Bierkens and Wada 2019). Reductions in recharge due to climate change can further exacerbate this situation (Konikow and Kendy 2005; Taylor et al. 2013; Kløve et al. 2014), and 
land-cover change can either amplify or reduce these effects (Candela et al. 2009; Van Roosmalen et al. 2009; Poelmans et al. 2010; Dawes et al. 2012; Pulido-Velazquez et al. 2015; Han et al. 2017; Mohan et al. 2018).

A range of groundwater sustainability policies have emerged in response to current and projected water resource degradation (Gleeson et al. 2012; Elshall et al. 2020). This includes sustainable yield and related policies, which limit groundwater pumping to levels that can be sustained over the long-term without compromising societally defined human and ecological uses of the resource (Hansen 2012; Pierce et al. 2013; Rudestam and Langridge 2014; Elshall et al. 2020). Second, watershed protection programs focused on maintaining or enhancing hydrologic ecosystem services, including groundwater recharge, are rapidly growing, particularly in the tropics (Abell et al. 2017; Salzman et al. 2018; Brauman et al. 2019). A key information need for both groundwater sustainable yield policies and watershed protection efforts is improved understanding of the relative impacts of watershed management on groundwater recharge and supply in a context of broader climate and land-cover change (Chun et al. 2017; Bremer et al. 2020). Furthermore, translating changes in groundwater recharge and supply into metrics directly related to groundwater management (e.g. change in sustainable yields, supply costs, number of households serviced, etc.) is critical to support integrated land and water management and funding decisions (Guswa et al. 2014; Kroeger et al. 2019; Wada et al. 2020).

However, there are few examples of hydrologic ecosystem services studies that link watershed ecohydrologic processes to economic and other well-being metrics (Brauman 2015), particularly in a context of climate change. The majority of existing valuation studies focus on the impacts of watershed protection on water quality rather than quantity (Keeler and Polasky 2014; Ozment et al. 2018; Kroeger et al. 2019), and those that do focus on groundwater ecosystem services directly link recharge to economic value (without consideration of groundwater dynamics) or utilize highly simplified groundwater modeling frameworks (Brauman 2015; Bremer et al. 2019; Burnett and Wada 2014; Wada et al. 2020). This leaves important gaps in the understanding of how spatially heterogeneous watershed management and aquifer dynamics influence the value of watershed management.

The importance of groundwater sustainability efforts is particularly important on islands, where there is often near complete reliance on groundwater, with few options for substitutes beyond desalination and water reuse (Izuka et al. 2018; Holding et al. 2016). The Hawaiian Islands, for example, rely heavily on groundwater, with $99 \%$ of drinking and half of all water use sourced from aquifers (Tribble 2008). As required by the Hawai'i State Water Code, sustainable yield limits have been established for all aquifers primarily by using a lumped groundwater model (Townscape 2019). The model, known as the Robust Analytical Model (RAM), is based on a steady-state assumption for an aquifer where inflows (recharge) equal outflows (leakage plus pumping), with all pumping lumped as a single value (Mink 1981). An improved version that accounts for salinity, RAM 2, was later introduced by Liu (2006). Although RAM 2 is useful in its simple and widely applicable approach, the state water regulator and others have identified the critical need to update sustainable yield estimates to better account for aquifer spatial heterogeneity, future land-cover and climate change, and groundwater flow to ecosystems (Chun et al. 2017; Townscape 2019; Burnett et al. 2020).

There is also increasing interest by Hawai $i$ water utilities, regulators, and land managers in quantifying the outcomes of watershed protection on groundwater recharge and supply in order to justify and guide investments (Bremer et al. 2015; Burnett et al. 2017; Povak et al. 2017; Roumasset and Wada 2015). Watershed protection activities in Hawai' $i$ primarily include efforts to protect native forests from invasion by nonnative ungulates and high-water-use invasive plant species (Burnett et al. 2017; Povak et al. 2017; Wada et al. 2017). While significant uncertainty remains on the impacts of species invasions on tropical ecohydrology (Hamel et al. 2017; Wright et al. 2018), a growing body of field studies suggest greater transpiration rates - and thereby lower groundwater recharge rates - in typical nonnative, invasive versus typical native forest stands (Giambelluca et al. 2008; Kagawa et al. 2009; Cavaleri et al. 2014). Several studies in Hawai'i have utilized water balance and other hydrologic models parameterized by limited field data to assess the impact of land cover, including watershed protection on groundwater recharge (Engott 2011; Burnett et al. 2017; Povak et al. 2017; Brewington et al. 2019), and linked economic metrics (Burnett and Wada 2014; Brauman et al. 2015; Bremer et al. 2019; Wada et al. 2020). However, none of these studies link groundwater recharge to management implications through a spatially explicit groundwater model to evaluate the combined effect of watershed protection and climate change.

Accordingly, the objective of this study is to inform land and groundwater policy in the most heavily utilized aquifer in Hawai' $i$ through assessment of the impact of future landcover change, including watershed management and urban development, on groundwater recharge, sustainable yield, and groundwater replacement costs, in a context of a dry future climate - representative concentration pathway (RCP) 8.5 mid-century (Elison Timm et al. 2014). In so doing, this study fills important gaps in groundwater ecosystem services valuation and provides a novel combination of participatory land-cover scenario development, sustainable yield estimation using a simulation optimization approach, and groundwater replacement cost analysis. This study also provides important lessons for Hawai' $i$ and other parts of the world, particularly for islands and other regions where groundwater is critical to water security, and where species invasions threaten source watersheds. 


\section{Methods}

\section{Study site}

The Pu'uloa (Pearl Harbor) aquifer, on the island of $\mathrm{O}^{\prime} \mathrm{ahu}$, is the most heavily utilized aquifer in the State of Hawai' $i$, supplying the majority of the island of $\mathrm{O}^{\prime}$ ahu's drinking water (Tribble 2008; Fig. 1). Whereas the Island of $\mathrm{O}^{\prime}$ ahu represents $50 \%$ of water demand across the state, it receives just $7 \%$ of statewide groundwater recharge. Accordingly, the island as a whole, and the Pu'uloa aquifer in particular, is of high concern for water security (Izuka et al. 2018). Mean rainfall in the region is $\sim 1,400 \mathrm{~mm} /$ year (based on the Hawai' $i$ Rainfall Atlas years 1978-2007; Giambelluca et al. 2013) and mean annual groundwater recharge is $553 \mathrm{~mm} /$ year (Engott et al. 2017). Variation in groundwater recharge is primarily driven by changes in rainfall which generally increases with elevation across the aquifer, from sea level to $\sim 900 \mathrm{~m}$ above sea level, but land cover also plays a role. Detailed information about the aquifer, including the geology and hydraulic properties of various formations, the groundwater flow system, and various recharge and discharge pathways, can be found in Oki (2005).
Due to its vital importance as a groundwater source and concerns about its long-term sustainability, the Pu'uloa aquifer has been the focus of a number of studies addressing groundwater management and sustainable yield policies (Mink 1980; Oki 2005; Liu 2006; Burnett et al. 2020). Designated as a groundwater management area by the state, the aquifer is protected by managing groundwater pumping through a permitting process. For management purposes, the aquifer is divided into three hydrologically connected systems: the Ewa-Kunia system, the Waipahu-Waiawa system, and the Waimalu system (Fig. 1a). This study covers the

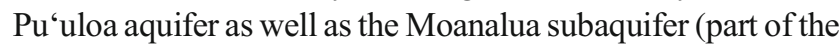
Honolulu aquifer), which is included as part of the groundwater modeling domain due to aquifer interconnectivity (Fig. 1; Oki 2005). Current pumping across the modeled area is 443 million liters per day (MLD).

From the late 1800s to the mid 1990s, much of the Pu'uloa aquifer pumping was used to supply sugarcane plantations, but the decline of sugar and large-scale conversion to suburban development shifted water allocation from agricultural to urban use (Wilcox 1996; Izuka et al. 2018). State land-use designations in the area are currently $\sim 30 \%$ conservation, $23 \%$ agriculture, and
Fig. 1 Pu'uloa (Pearl Harbor) aquifer, Island of O'ahu, Hawai' $\mathrm{i}$ (USA): a groundwater wells where pumping is greater than 3.8 million liters per day (MLD) and springs; $\mathbf{b}$ baseline land cover. Note that "alien forest" refers to forest dominated primarily by nonnative (nonindigenous) species; the term "nonnative forest" is used in the text
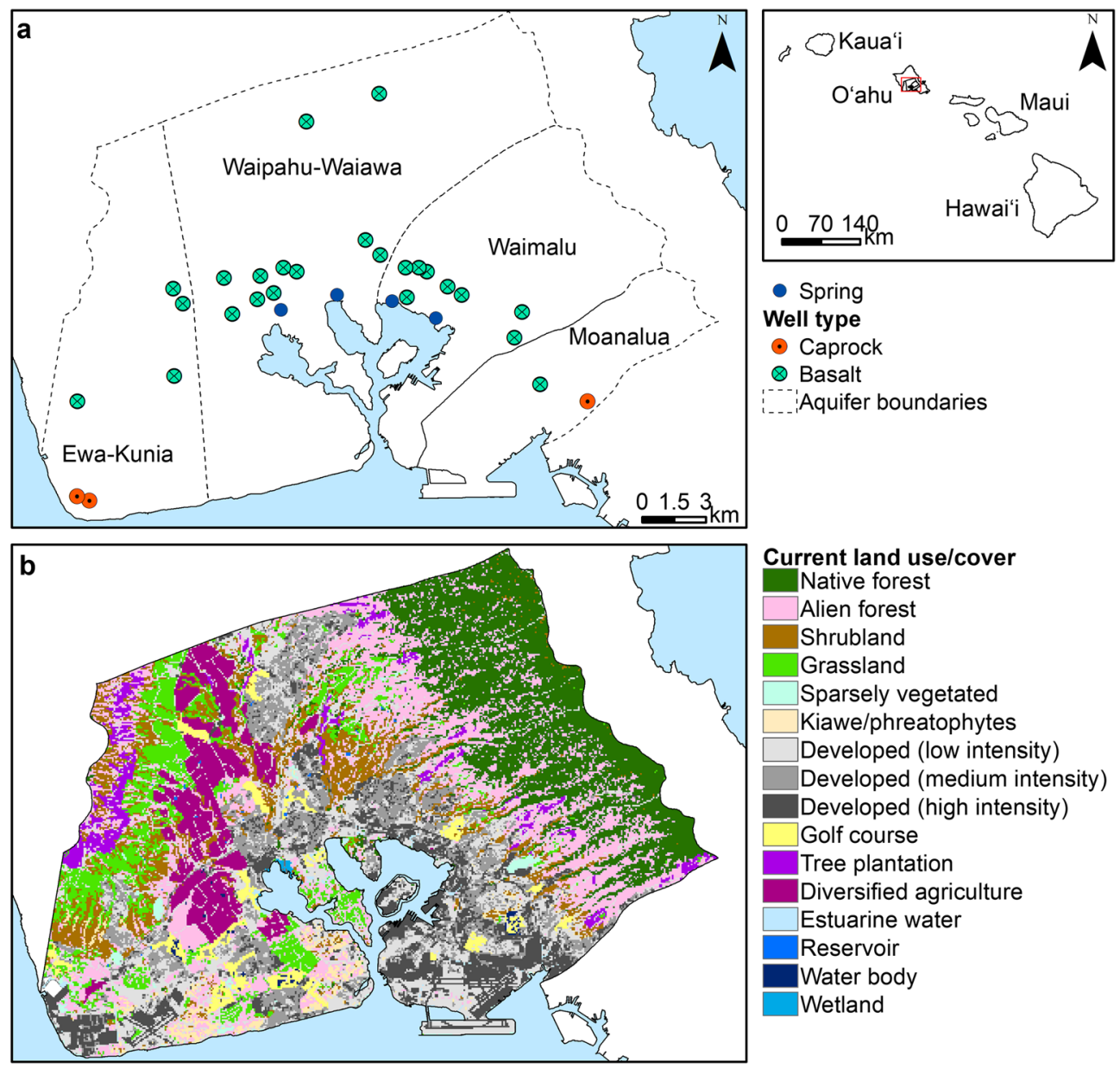

Current land use/cover

Native forest

Alien forest

Shrubland

Grassland

Sparsely vegetated

Kiawe/phreatophytes

Developed (low intensity)

Developed (medium intensity)

Developed (high intensity)

Golf course

Tree plantation

Diversified agriculture

Estuarine water

Reservoir

Water body

Wetland 
47\% urban (State of Hawai $i$ 2019). The future of agricultural lands is highly uncertain as up to $40 \%$ of agricultural lands across the state are currently unfarmed, yet there is strong interest in revitalizing agricultural systems (Miles 2020). Over the last 50 years, suburban development has occurred over vast areas of former plantation lands, whereas there is currently a push towards denser development, particularly around the planned elevated rail system. However, the trajectory of urban development and how this intersects with agricultural lands is highly uncertain.

Much of the remaining native forest in conservation lands are is threatened by invasive plant species (e.g. strawberry guava; Psidium cattleianum), which available research suggest have higher transpiration rates than typical native forest species (e.g. 'ōhi'a lehua; Metrosideros polymorpha; Giambelluca et al. 2008, 2014; Burnett et al. 2017). In an effort to protect existing native forests for their biodiversity and cultural value as well as for potential links to groundwater recharge, the Ko'olau Mountains Watershed Partnership, the state conservation agency (Department of Land and Natural Resources, Division of Forestry and Wildlife) and others, work to prevent the spread of invasive species through ungulate fences and invasive plant control. Fences both protect native forest from degradation of the understory and also help to slow the spread of nonnative, invasive plant species. There is a strong interest on the part of these organizations, as well as the Honolulu Board of Water Supply (the local water utility that also invests in source watershed protection), and the Commission on Water Resources Management (the water regulator and administrator of the State Water Code) to understand the implications of watershed protection efforts in terms of hydrologic as well as economic and other well-being metrics.

\section{Land-cover scenarios}

The baseline land cover (Fig. 1b) used in this study is based on a $2010 \mathrm{O}^{\prime}$ ahu land-cover map developed by the United States Geological Survey (USGS) for estimating groundwater recharge (Engott et al. 2017), which is largely based on the LANDFIRE product (LANDFIRE 2012). In order to evaluate the potential effect of a range of future land-cover possiblities, including changes in watershed management (forest protection) and urban development, this study developed stakeholder-informed, spatially-explicit scenarios of future land cover over 50 years (2021-2070). In total, six scenario maps were created representing plausible future land-cover changes based on input from key land managers, including the Hawai'i State Office of Planning, the City and County Department of Planning and Permitting, The State of Hawai'i Department of Land and Natural Resources, Division of Forestry and Wildife (DOFAW), and the Ko'olau Mountains Watershed Partnership (Fig. 2). All land-cover scenarios and resulting groundwater recharge estimates are publicly available (Brewington et al. 2020).

\section{Watershed management scenarios}

Drawing from engagement with DOFAW and the Ko'olau Mountains Watershed Partnership, three future watershed management scenarios were created: high-forest-protection (Fig. 2a,d); targeted-forest-protection (Fig. 2b,e); and noforest-protection (Fig. 2c,f). In high-forest-protection, all existing native forest $(8,186 \mathrm{ha})$ is protected from invasion of nonnative forest through ungulate fencing and invasive plant species control. This is considered a best-case scenario by land managers given the challenge and cost of restoring nonnative forest to native forest. The targeted-forest-protection scenario focuses on protecting areas within existing and planned ungulate fences $(\sim 2,409 \mathrm{ha})$. This scenario represents a desirable and plausible scenario (assuming continued funding and support). Finally, the no-forest-protection scenario represents a perceived worst-case scenario where no fences are established and no conservation activities take place.

Based on input from the watershed management stakeholders, and following Brewington et al. (2019), it was assumed that areas enclosed by fences are protected and do not convert to nonnative forest. To estimate the spread of nonnative forest outside of fenced areas in no-forestprotection and targeted-forest-protection scenarios, a spread model developed by Bremer et al. (2019) was adapted to assess the trajectory of invasion of nonnative forest into native forest in East Maui. In the absence of fencing, this study evaluated $5 \%$ and $10 \%$ annual spread rates based on ranges estimated from watershed manager input and an existing study (Geometrician Associates 2010; Bremer et al. 2019). Starting from the baseline land-cover map, $5 \%$ of native forest pixels adjacent to existing nonnative forest are converted to nonnative forest each year over 50 years. Given that spread can occur in different spatial configurations, 1,000 simulations of potential spread pathways were run over the 50 years. Full conversion is reached after 13 years for the 5\% spread and 9 years for the $10 \%$ spread assumptions respectively. In both cases, full forest conversion is reached far before the 50year time period, so complete conversion of native to nonnative forest outside of fenced areas was assumed in both the noforest-protection and targeted-forest-protection scenarios. Full conversion refers to near stabilization $(<0.5 \%$ of forest pixels outside of fenced areas remaining native forest). After this point, conversion of the last remaining native forest pixels that are not adjacent to nonnative forest is slow.

\section{Urban development scenarios}

The watershed management scenarios were crossed with two scenarios of urban development. Urban development is important to consider as this is a major land-cover change projected to occur within the region over the coming decades (Calthorpe Associates 2013), and there are important 


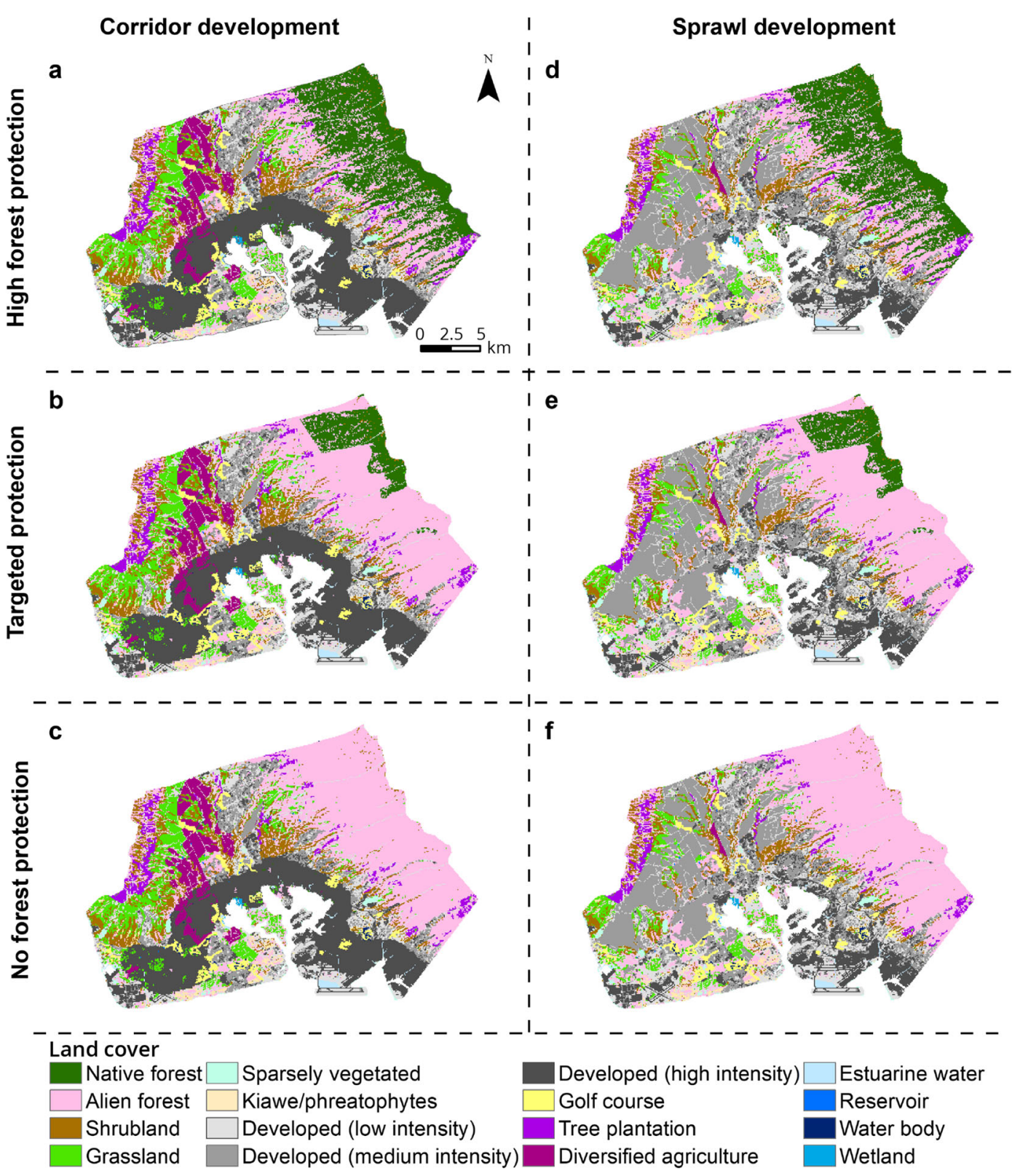

Fig. 2 Stakeholder-informed future forest protection and urban development land-cover scenarios: a corridor development + highforest-protection; b corridor development + targeted-forest-protection; c

corridor development + no-forest-protection; d sprawl development + high-forest-protection; e sprawl development + targeted-forestprotection; $\mathbf{f}$ sprawl development + no-forest-protection

questions around how these changes will affect groundwater recharge and sustainable yield. Stakeholders emphasized that it is extremely unlikely that future urban development will occur on conservation lands so all development scenarios considered only areas zoned as urban and agriculture.

With input from the City and County of Honolulu Department of Planning and Permitting and the State of Hawai' ${ }^{i}$ Office of Planning, two urban development scenarios were developed: (1) corridor development (Fig. 2a-c); and (2) urban sprawl (Fig. 2d-f). As recommended by the City and County of Honolulu, these are based on two qualitative scenarios developed in Calthrope (2013) as part of the City and
County of Honolulu's transit oriented development (TOD) planning efforts. Transit oriented development refers to development around a $0.6-\mathrm{km}$ radius of the planned elevated rail system on $\mathrm{O}^{\prime}$ ahu, with the Pu'uloa aquifer. In line with stakeholder interests, this study focuses on broad urban development trendsdense versus sprawl development-representing two extremes of potential future urban development.

Both scenarios include the two major planned developments, of 3,500 residential units (Koa Ridge) and 11,750 residential units (Ho'opili). In the first scenario, corridor development, all existing low- and medium-intensity development within the $0.6-\mathrm{km}$ corridor become high-intensity development 
(6,084 ha). Agricultural lands, golf courses, and native ecosystems were not converted within the corridor area, with the exception of the planned Ho'opili development, and no development occurs beyond the corridor with the exception of the Ho 'opili and Koa Ridge developments. The corridor development scenario is roughly based on the TOD corridor focus narrative (Calthorpe Associates 2013), and is considered a best-case scenario in terms of the reduction of urban sprawl, which city and state planners hope to avoid due to multiple concerns including land conversion and infrastructure limitations.

In the second urban development scenario, sprawl development, all agricultural lands within and outside the rail corridor, with the exception of a small amount of land designated as "important agricultural lands" (IAL) (State of Hawai'i Land Use Commission 2019), are converted to medium-intensity development $(8,225 \mathrm{ha})$. The current agricultural lands available for sprawl development was updated using the Hawai' $i$ Agricultural Baseline (Melrose 2015). The sprawl development scenario is roughly based on the TOD "business as usual" narrative, and is considered worst-case in the sense that the majority of development occurs on previously undeveloped land in a similar pattern to suburban development over the last several decades. The two urban development scenarios and the three watershed protection scenarios were combined to generate six final future land-cover scenarios for the Pu'uloa aquifer (Fig. 2; Table 1).

\section{Groundwater recharge and sustainable yield estimates}

Spatially explicit estimates of annual groundwater recharge for each land-cover scenario were estimated by using the
Hawai'i Groundwater Recharge Tool (Mclean et al. 2019; Fig. 3). The tool uses recharge values computed using the Soil-Water-Balance (SWB) code version 2.0 for Hawai' $i$ (Westenbroek et al. 2018; Mclean et al. 2019a, b), which employs a modified Thornthwaite-Mather soil-moisture accounting method (Thornthwaite and Mather 1955, 1957) to calculate net infiltration. The SWB calculates the distribution and timing of net infiltration out of the root zone, as well as other components of the water balance, including soil moisture, reference and actual evapotranspiration, snowfall, snowmelt, canopy interception, and crop-water demand. The SWB uses gridded datasets, including datasets describing hydrologic soil groups, moisture-retaining capacity, flow direction, and land use. Net infiltration rates are computed using a rectangular grid for direct importation into grid-based groundwater flow models. The primary data requirements include precipitation, temperature, land cover, hydrologic soil group, flow direction, and soil-water capacity (Westenbroek et al. 2018).

Parameter values were derived from spatial datasets compiled for Hawai'i in Engott et al. (2017) and Izuka et al. (2018). Variations of this water balance approach have been used to generate recharge estimates across the Hawaiian Islands and are the most common source of groundwater recharge information utilized by resource managers (Johnson et al. 2014; Engott et al. 2017; Brewington et al. 2019). Each land-cover scenario was run under the baseline climate (1978-2007; Giambelluca et al. 2013) and a dry future climate scenario RCP 8.5 mid-century (Elison Timm et al. 2014) commonly used in management and research in Hawai' $i$ (Wada et al. 2017; Brewington et al. 2019). While RCP 8.5 was initially considered an extreme scenario, historical and current emissions

Table 1 Pu'uloa aquifer land-cover scenario narratives. $M L D$ million L/day, IAL important agricultural lands

\begin{tabular}{|c|c|c|}
\hline Scenario & Description & $\begin{array}{l}\text { Groundwater } \\
\text { recharge (MLD) } \\
\text { baseline climate }\end{array}$ \\
\hline Baseline land cover & USGS 2010 land-cover map & 758 \\
\hline $\begin{array}{l}\text { Scenario 1: Corridor development+ } \\
\text { high-forest-protection }\end{array}$ & $\begin{array}{l}\text { High-intensity urban development occurs within a } 0.6 \mathrm{~km} \text { radius of the rail } \\
\text { corridor. All current agricultural lands are protected. All existing native } \\
\text { forest is protected. }\end{array}$ & 744 \\
\hline $\begin{array}{l}\text { Scenario 2: Corridor development+ } \\
\text { targeted-forest- protection }\end{array}$ & $\begin{array}{l}\text { High-intensity urban development occurs within a } 0.6 \mathrm{~km} \text { radius of the rail } \\
\text { corridor. All current agricultural lands are protected. All native forest } \\
\text { within existing and planned fencing and management areas is protected. }\end{array}$ & 716 \\
\hline $\begin{array}{l}\text { Scenario 3: Corridor development+ } \\
\text { no-forest-protection }\end{array}$ & $\begin{array}{l}\text { High-intensity urban development occurs within a } 0.6 \mathrm{~km} \text { radius of the rail } \\
\text { corridor. All current agricultural lands are protected. Nearly all existing } \\
\text { native forest is converted to nonnative forest given a lack of protection. }\end{array}$ & 707 \\
\hline $\begin{array}{l}\text { Scenario 4: Sprawl development+ } \\
\text { high-forest- protection }\end{array}$ & $\begin{array}{l}\text { Medium-intensity urban development sprawls across all agricultural lands } \\
\text { (except those designated as IAL). All existing native forest is protected. }\end{array}$ & 739 \\
\hline $\begin{array}{l}\text { Scenario 5: Sprawl development+ } \\
\text { targeted-forest- protection }\end{array}$ & $\begin{array}{l}\text { Medium-intensity urban development sprawls across all agricultural lands } \\
\text { (except those designated as IAL). All native forest within existing and } \\
\text { planned fencing and management areas is protected. }\end{array}$ & 711 \\
\hline $\begin{array}{l}\text { Scenario 6: Sprawl development+ } \\
\text { no-forest-protection }\end{array}$ & $\begin{array}{l}\text { Medium-intensity urban development sprawls across all agricultural lands } \\
\text { (except those designated as IAL). Nearly all existing native forest is } \\
\text { converted to nonnative forest given a lack of protection. }\end{array}$ & 702 \\
\hline
\end{tabular}


Fig. 3 Flow diagram of the modeling framework: $\mathbf{a}-\mathbf{b}$ scenarios of climate change and land cover are $\mathbf{c}$ inputs into the Hawai'i Groundwater Recharge Tool which utilizes the Hawai' $i$ Soil Water Balance model to generate recharge estimates, which then are $\mathbf{d}$ inputs into the groundwater simulation optimization. e Final outputs are estimates of sustainable yield, spring and submarine discharge, and groundwater replacement costs for each scenario

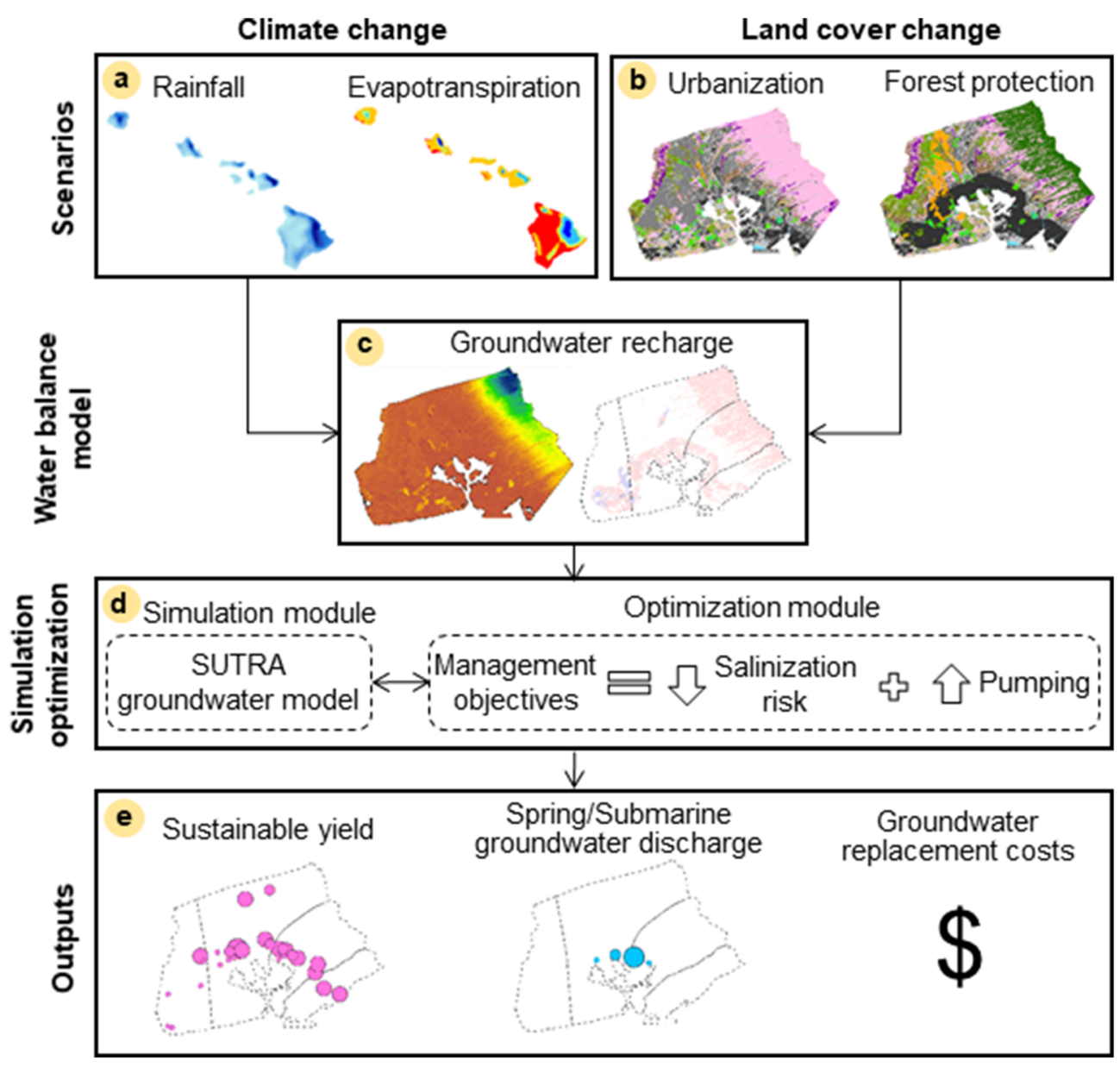

are consistent with this scenario, and RCP 8.5 is currently seen as the most useful mid-century climate projection (Sanford et al. 2014; Schwalm et al. 2020). Accordingly, this study used the current climate as a low-range potential future climate, and RCP 8.5 mid-century a mid- to upper-range projection.

This study applied a sequential approach where a surfacewater model was used to estimate recharge for the groundwater model, also known as loose-coupling (Elshall et al. 2020). Elshall et al. (2020) provides a detailed discussion of the pros and cons of loose-coupling versus coupled or integrated hydrologic modeling approaches. Models applying the latter approach are more accurate in estimating recharge through infiltration due to improved accounting for the dynamics of evaporation over space and time (Elshall et al. 2020). Fully coupled models are generally more suitable for integrated management of surface and subsurface resources under land-use change, climate variability, and groundwater pumping. However, coupled and integrated models are typically complex and involve substantial simulation uncertainty due to data shortages. This simulation uncertainty would substantially hinder the current study in applying a numerical model within an optimization framework. This study thus used a loose-coupling modeling approach, which is an accepted and widely used methodology (Elshall et al. 2020).
Recharge results were then combined with a groundwater simulation optimization approach to estimate sustainable yield (Burnett et al. 2020). Simulation optimization is a technique that solves an objective function stating the management objectives aided by the simulation models and an optimization algorithm to find optimal management solutions. The transient finite element groundwater SUTRA model of the Pu'uloa aquifer (Oki 2005) was used to simulate groundwater flow and salinity distribution. This model, a modified version of SUTRA 2.0 (Voss and Provost 2002), was designed to simulate three-dimensional (3D) variable-density groundwater flow and solute transport in heterogeneous anisotropic aquifers. The model's domain extends vertically to coincide with an assumed aquifer bottom, and is laterally defined by no-flow, recharge, or specified-pressure boundaries. Pumping wells are represented by distributing the well fluxes over the nearest vertical column of nodes. Springs are simulated as functions of simulated head levels. Oki (2005) calibrated the model using published data to constrain values for permeability, storage, and a spreading-related parameter.

For the 50-year design period from 2021 to 2070, the simulation optimization approach estimated the maximum allowable pumping (or sustainable yield) in the Pu'uloa aquifer without violating salinity and drawdown constraints to ensure the long-term quality of the aquifer (Fig. 3). Salinity constraints 
were set to $250 \mathrm{mg} / \mathrm{L} \mathrm{Cl}$ following the Environmental Protection Agency's secondary standard for drinking water, with the exception of the wells in the nearshore caprock formation, for which the salinity constraint was set to $1,000 \mathrm{mg} / \mathrm{L} \mathrm{Cl}$, as some of these wells are naturally brackish and are not used for potable supply (Fig. 1a). The drawdown constraint in pumping wells was set to a maximum allowable drawdown of 5-meters from predevelopment water-levels as defined by the water regulator. The simulation optimization procedure utilizes the covariance matrix adaptation-evolution strategy (CMA-ES, Hansen et al. 2003), with parallel computing implementation (Elshall et al. 2015). CMA-ES is a stochastic derivative-free optimization algorithm that numerically estimates a covariance matrix of the decision variables to learn about the underlying objective function:

$f=\sum_{i=1}^{\mathrm{m}} q_{i} \times p_{i}\left\{\begin{array}{cc}p_{i}=-1 & \forall W_{i, \mathrm{obs}}>W_{i, \text { threshold }} \\ p_{i}=1 & \forall W_{i, \mathrm{obs}} \leq W_{i, \text { threshold }}\end{array}\right.$

to find the total maximum allowable pumping without violating these constraints, for any $m$ number of pumping wells (decision variables). A withdrawal dependent objective function was used such that the candidate solution value was be penalized if the chloride concentration or drawdown $W_{i \text {, obs }}$ in any pumping well $i$ exceeded the chloride concentration or

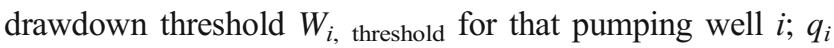
and $p_{i}$ are the pumping rate and penalty term of pumping well $i$, respectively. The chloride concentration and drawdown $W_{i \text {, obs }}$ was observed at the end of the simulation period. Five nodes were used for each simulation optimization run. The simulation optimization was run for 200 iterations with an average iteration time of $\sim 0.4 \mathrm{~h}$ using the standard nodes of the University of Hawai'i (UH) high performance computing (HPC) cluster. Each standard node had dual socket Intel Xeon E5-2680 v2 (10-core @ 2.8GHz) and 128 GB of RAM.

As a point of comparison, a forward model run of the SUTRA $\mathrm{Pu}^{6}$ uloa model for the region was also conducted assuming that the current pumping allocation continues for 50 years. The forward model run solution was compared with the optimized sustainable yield estimates to evaluate the benefit of optimization.

\section{Groundwater replacement costs}

Groundwater replacement costs were estimated based on groundwater consumption projections developed by the Honolulu Board of Water Supply (HBWS 2016), which currently serves roughly one million customers on $\mathrm{O}^{\prime} \mathrm{ahu}$, including those residing in the regions overlying and surrounding the $\mathrm{Pu}$ 'uloa aquifer. Demand projections were driven by two primary factors: (1) population growth and (2) changes in per capita demand. In HBWS's moderate demand growth scenario, HBWS assumes that the population continues to grow through 2040, while per capita demand for each customer declines over time. The HBWS high demand growth scenario assumes that per capita demand remains constant over time for the existing population, while per capita demand declines for new future users owing to the utility's planned water conservation initiatives and expected reductions in potable water irrigation. Although demand projections are tied to land use districts rather than aquifers, it was assumed that the $\mathrm{Pu}$ 'uloa aquifer will continue to supply surrounding districts in the future, including the primary urban core and surrounding areas. In 2012, the base year for the projections, demand for the four districts of interest (Ewa, Central O'ahu, East Honolulu, Primary Urban Center, HBWS 2016) totaled 424.7 MLD. The aggregated projected demand in 2040 is 468.6 MLD and 500.8 MLD for the moderate- and high- demand growth scenarios respectively. These values correspond to average annual demand growth rates of 0.35 and $0.59 \%$. Assuming that the rate of demand growth remains constant, the projections were extended to year 2070, which resulted in final-period demands of 520.8 MLD (moderate growth) and 597.3 MLD (high growth).

$D_{2070}=e^{g(2070-2012)} D_{2012}$
where $g=\ln \left(\frac{D_{2040}}{D_{2012}}\right) /(2040-2012)$

such that $D_{2012}, D_{2040}$, and $D_{2070}$ are the observed or projected quantities of water demanded in millions of liters per day for years 2012, 2040, and 2070 respectively. For each land-cover and climate scenario, the year 2070 shortfall was calculated under each of the demand growth assumptions (moderate and high) as the difference between the sustainable yield estimate generated by the simulation optimization module and the final-period demand projection. In the cases where estimated sustainable yield exceeds projected demand, expected shortfall in 2070 is zero. Replacement costs in year 2070 were then calculated by multiplying the estimated shortfall for each land use and climate scenario by $\$ 2.38 \mathrm{USD} / 1,000 \mathrm{~L}$, based on a recent estimate of the unit cost of desalination in Maui, Hawai'i (MCDWS 2019). Note that the estimated replacement cost for each scenario is the cost of bridging the gap between sustainable yield and demand using desalination in year 2070, i.e., not aggregated over the 50-year planning period.

\section{Results}

\section{Groundwater recharge}

Under baseline land cover, groundwater recharge is projected to decline by $\sim 16 \%$ (from 758 to 638 MLD) under RCP 8.5 midcentury rainfall compared with baseline rainfall conditions (Fig. 4; 
Table 2 Sustainable yield, spring discharge, and replacement costs (under two demand growth assumptions) of land-cover scenarios

\begin{tabular}{|c|c|c|c|c|c|}
\hline \multirow[t]{2}{*}{ Scenario } & \multirow[t]{2}{*}{$\begin{array}{l}\text { Recharge } \\
\text { (MLD) }\end{array}$} & \multirow{2}{*}{$\begin{array}{l}\text { Optimized } \\
\text { sustainable Yield } \\
\text { (MLD) }\end{array}$} & \multirow{2}{*}{$\begin{array}{l}\text { Spring } \\
\text { discharge } \\
\text { (MLD) }\end{array}$} & \multicolumn{2}{|c|}{$\begin{array}{l}\text { Replacement cost } \\
\text { (million \$US/year) }\end{array}$} \\
\hline & & & & $\begin{array}{l}\text { Moderate } \\
\text { demand }\end{array}$ & $\begin{array}{l}\text { High } \\
\text { demand }\end{array}$ \\
\hline \multicolumn{6}{|l|}{ Baseline climate } \\
\hline Baseline landcover & 758 & 575 & 234 & 0 & 19 \\
\hline \multicolumn{6}{|l|}{ RCP 8.5 mid-century rainfall } \\
\hline Baseline landcover & 638 & 481 & 236 & 35 & 101 \\
\hline $\begin{array}{l}\text { 1: Corridor development; } \\
\text { high-forest-protection }\end{array}$ & 633 & 473 & 238 & 41 & 108 \\
\hline $\begin{array}{l}\text { 2: Corridor development; } \\
\text { targeted-forest-protection }\end{array}$ & 606 & 439 & 240 & 71 & 137 \\
\hline $\begin{array}{l}\text { 3: Corridor development; } \\
\text { no-forest-protection }\end{array}$ & 595 & 428 & 243 & 81 & 147 \\
\hline $\begin{array}{l}\text { 4: Sprawl development; } \\
\text { high-forest-protection }\end{array}$ & 629 & 458 & 238 & 54 & 121 \\
\hline $\begin{array}{l}\text { 5: Sprawl development; } \\
\text { targeted-forest-protection }\end{array}$ & 602 & 435 & 235 & 74 & 141 \\
\hline $\begin{array}{l}\text { 6: Sprawl development; } \\
\text { no-forest-protection }\end{array}$ & 592 & 428 & 241 & 81 & 147 \\
\hline
\end{tabular}

Table 2). Reductions in recharge occur across the study area, with the exception of golf courses where recharge increases slightly (shown in blue areas in Fig. 4c due to increases in irrigation). Reductions are greatest in high elevation forested areas (Fig. 4).

Land-cover change has an important, but less significant impact on recharge than climate change. Specifically, recharge is projected to be $1-7 \%$ lower in the future land-cover scenarios compared to the baseline land cover across both climate scenarios (Tables 1 and 2). The greatest reduction in recharge due to land-cover change is in scenario 6 (no-forest-protection and sprawl development), which reduces recharge by 56 MLD under the baseline climate and 46 MLD under RCP 8.5 mid-century climate compared to the baseline land-cover (Fig. 5; Tables 1 and 2). In contrast, compared to the baseline
Fig. 4 Groundwater recharge under baseline land cover and $\mathbf{a}$ baseline and $\mathbf{b}$ RCP 8.5 midcentury rainfall. $\mathbf{c}$ Change in groundwater recharge from baseline to RCP 8.5 mid-century.

Note that areas with recharge $>4000 \mathrm{~mm} /$ year are minimal and primarily reservoirs
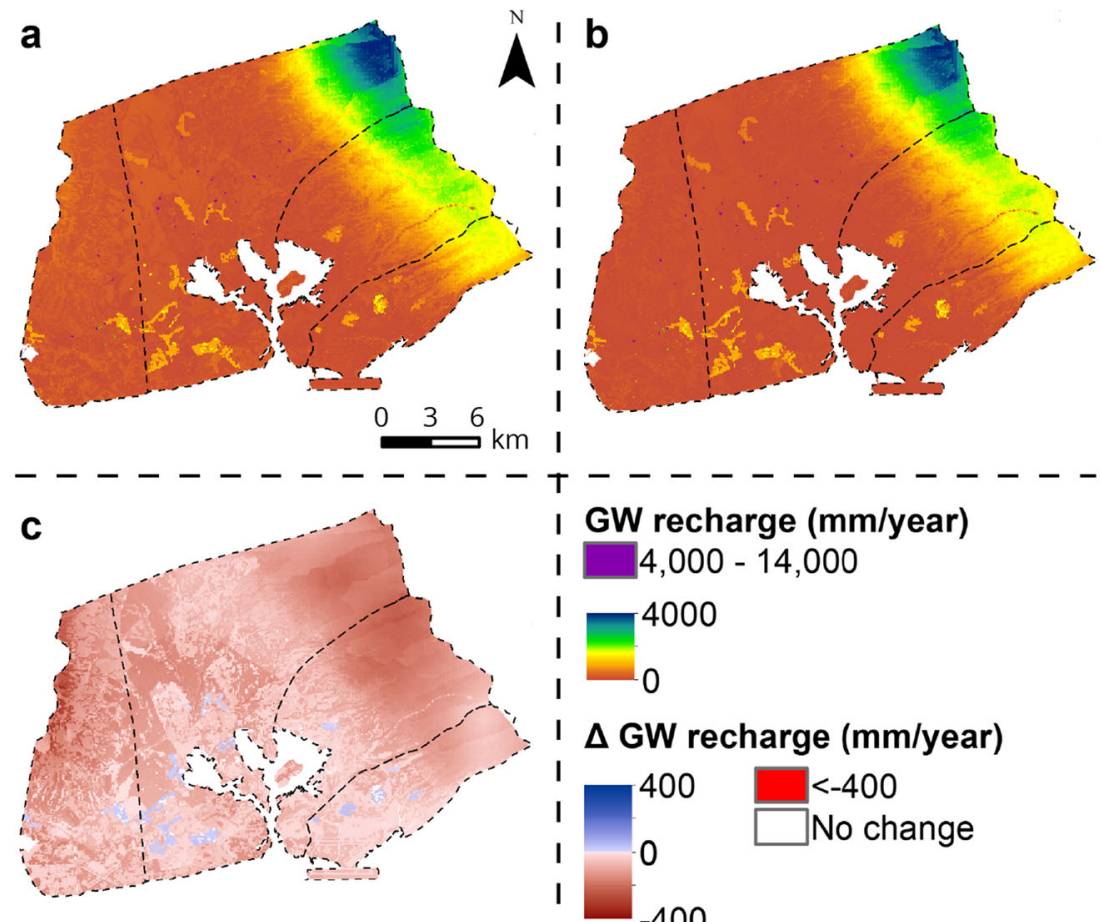
Fig. 5 Changes in recharge as a result of a transition from the baseline land cover to scenario 6 (urban sprawl and no-forestprotection) under baseline and RCP 8.5 mid-century rainfall. a Baseline land cover only where change occurs; b scenario 6 land cover only where change occurs; c land-cover-induced change in recharge under baseline climate; $\mathbf{d}$ land-cover-induced change in recharge under RCP 8.5 midcentury rainfall
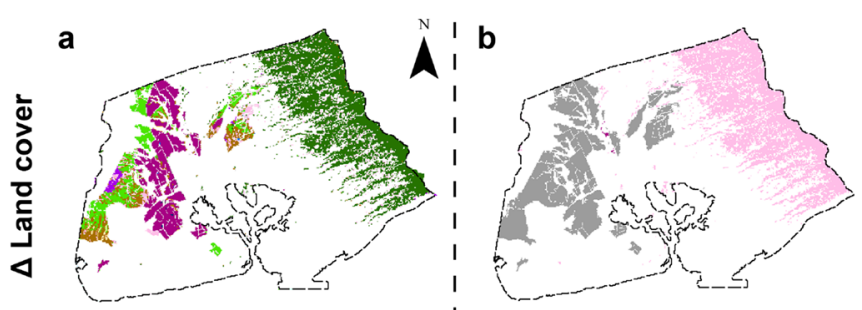

Baseline land cover $0 \quad 3.5 \quad 7$

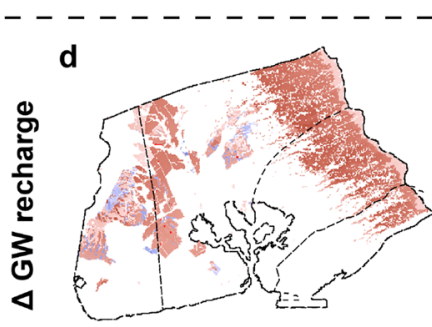

Baseline climate

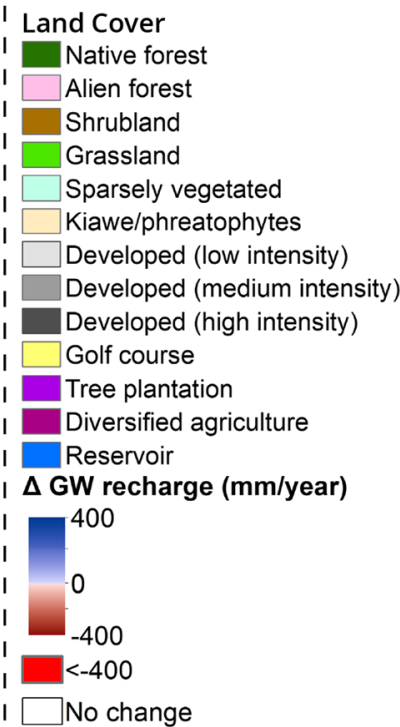

land cover, scenario 1 (high-forest-protection and corridor development) reduces recharge by a much smaller amount (14 MLD under the baseline climate and 5 MLD under RCP 8.5 mid-century climate; Fig. 6). The conversion of native forest and urban development decreases recharge across the majority of the study area, with the exception of small areas where nonnative forest, grassland, and tree plantation areas are converted to urban development or where medium-intensity is converted to high-intensity development (Figs. 5 and 6).

Collectively, the projected benefits of informed land-cover planning (i.e. avoided sprawl and high-forest-protection), or the difference between scenario 1 (high-forest-protection and corridor development) and scenario 6 (no-forest-protection and sprawl development), is a $6 \%$ increase in groundwater recharge. Specifically, recharge in scenario 1 is 42 MLD higher than scenario 6 in the baseline climate, and 41 MLD higher under RCP 8.5 mid-century rainfall (Fig. 7). The degree of watershed protection is the most important land-cover signal, making a far bigger difference than the trajectory of urban development. Holding urban development constant, recharge under high- and targeted-forest-protection is 5-6\% (37-38 MLD) and 1-2\% (9-11 MLD) higher than no-forestprotection, respectively across both climate scenarios (Tables 1 and 2). The greatest benefits of forest protection peaks in the 250-400-meter elevation band. Controlling for the forest protection scenario, recharge under corridor
Fig. 6 Changes in recharge as a result of a transition from the baseline land cover to scenario 1 (corridor development and high-forest-protection) under baseline and RCP 8.5 midcentury rainfall. a Baseline land cover only where change occurs; b scenario 1 land cover only where change occurs; $\mathbf{c}$ landcover-induced change in recharge under baseline climate; $\mathbf{d}$ landcover-induced change in recharge under RCP 8.5 mid-

century rainfall
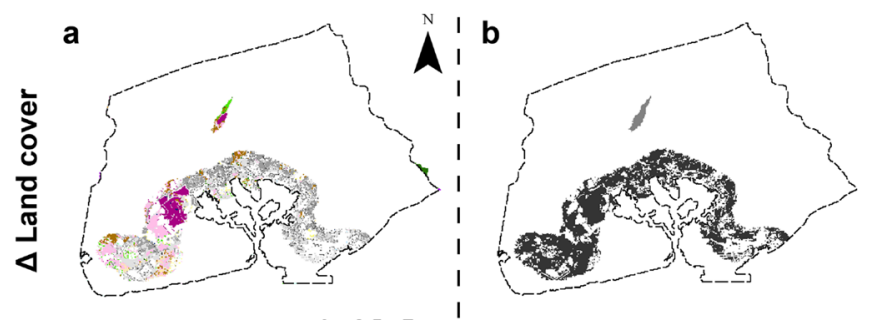

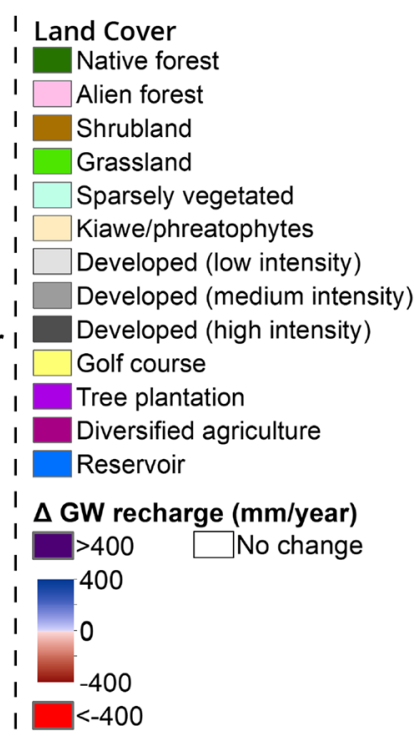


Fig. 7 Groundwater recharge in scenario 1 (corridor development and high-forest-protection) versus scenario 6 (sprawl development and no-forest-protection) under baseline and RCP mid-century rainfall. a Scenario 1 only where land-cover change occurs; b scenario 6 only where change occurs; $\mathbf{c}$ land-coverinduced change (difference between scenario 1 and 6) in recharge under baseline climate; $\mathbf{d}$ land-cover-induced change (difference between scenario 1 and 6) in recharge under RCP 8.5 mid-century
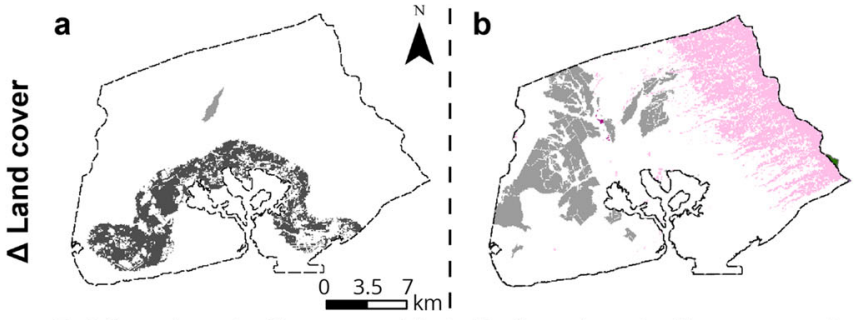

Full forest protection + corridor No forest protection + sprawl

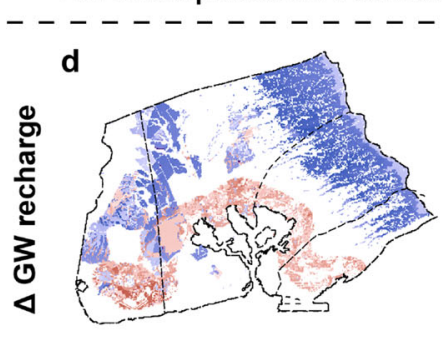

Baseline climate

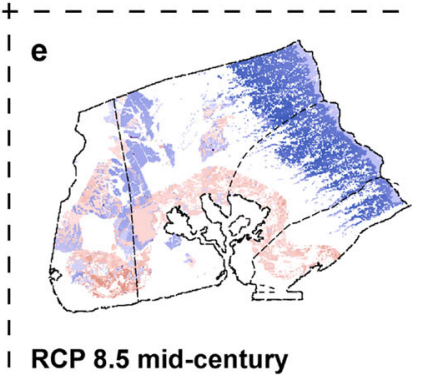

Land Cover

I Native forest

$1 \square$ Alien forest

I Shrubland

Grassland

Sparsely vegetated

$\square$ Kiawe/phreatophytes

$\square$ Developed (low intensity)

Developed (medium intensity)

Developed (high intensity)

Golf course

Tree plantation

Diversified agriculture

Reservoir

$\Delta \mathrm{GW}$ recharge (mm/year)

I $\square$ >00 $\square$ No change

400

0

$-400$ development is $>1 \%$ or (3-5 MLD) higher than sprawl development across both climate scenarios.

\section{Groundwater sustainable yield and replacement costs under a dry future climate and varied land-cover futures}

Sustainable yield estimates are projected to decrease by $16 \%$ (94 MLD) under RCP 8.5 mid-century compared to the baseline climate (Table 1; Fig. 8). Reductions occur across the aquifer, with the exception of the Waimalu aquifer region where optimal pumping remains about the same. The most significant reductions are in the Waipahu-Waiawa and Ewa-
Kunia subaquifers (Fig. 8). Compared to the current climate, RCP 8.5 mid-century conditions increase annual groundwater replacement costs by $\$ 35$ million USD/year under moderatedemand assumptions and $\$ 82$ million USD/year under highdemand assumptions.

Under RCP 8.5 mid-century, sustainable yield is projected to be $10 \%$ (45 MLD) higher under scenario 1 (high-forestprotection, corridor development) compared to scenario 6 (no-forest-protection, sprawl development). This translates to a $\$ 40$ and $\$ 39$ million USD/year difference in annual replacement costs under both moderate- and high-demand scenarios, respectively. As with recharge, the biggest driver of this change is the level of watershed protection. High-forest-
Fig. 8 a Optimal sustainable yield by well under baseline land cover and climate; $\mathbf{b}$ difference in sustainable yield between baseline and RCP 8.5 midcentury climate by aquifer unit

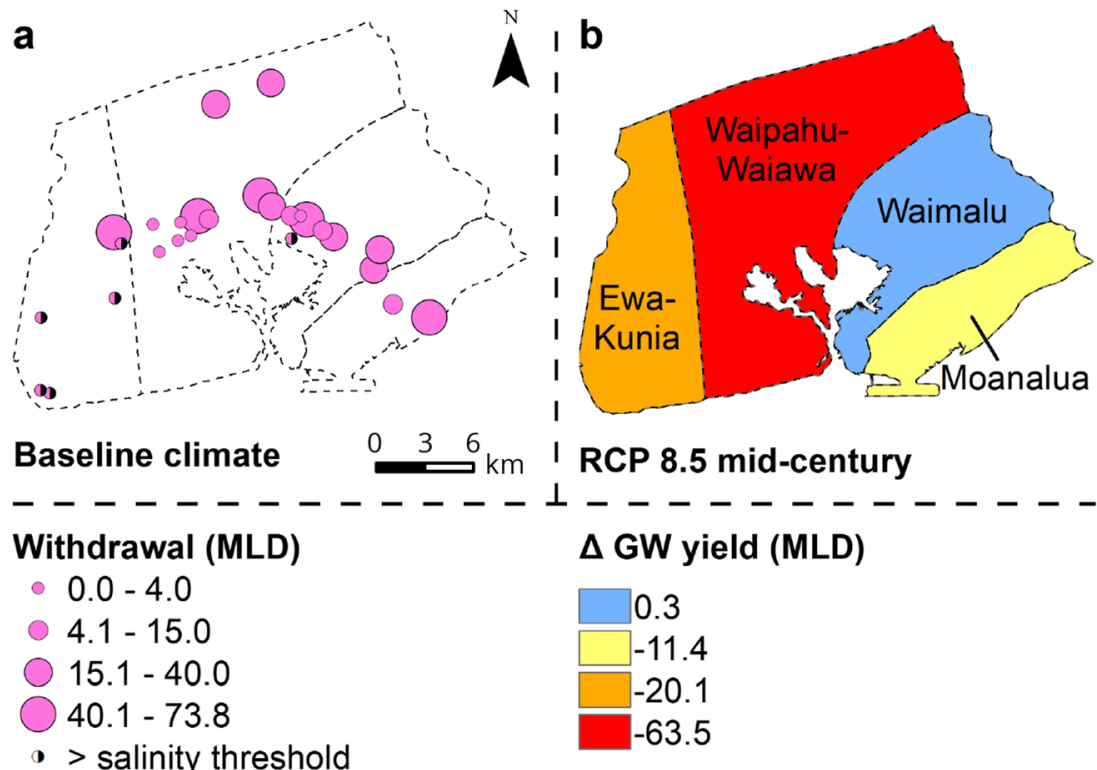


protection and targeted-forest-protection increases sustainable yield by $30-45$ MLD (7-11\%) and by 7-11 MLD (2-3\%), respectively across development scenarios compared to noforest-protection. The difference in sustainable yield and associated value of forest protection is higher under corridor development ( $\$ 10$ million USD for targeted-forest-protection and \$39-40 million USD for high-forest-protection) than sprawl development (\$6-7 million USD for targeted-forestprotection and \$26-27 million USD for high-forestprotection; Table 2). This is due to a lower sustainable yield under sprawl development for high-forest-protection and targeted-forest-protection, but equal sustainable yield under no-forest-protection. The type of urban development has a much lower impact on sustainable yield, with corridor development increasing sustainable yield by $0-15$ MLD compared to sprawl development, depending on the forest protection scenario.

As with climate change, land-cover change (Fig. 9), particularly forest loss, has the largest impact in the Waipahu-Waiawa subaquifer; however, in contrast to climate change, land-cover change, both sprawl and forest loss also reduces sustainable yield substantially in the Waimalu subaquifer. Sprawl development also results in small further reductions in the Ewa aquifer region, while forest loss reduces pumping in the Moanalua subaquifer, particularly under corridor development (Fig. 9). Spring discharge is similar across all scenarios (Table 2).

Additionally, the simulation optimization approach increases the amount of freshwater that can be withdrawn compared to current pumping allocations. Under current pumping distribution, $12 \%$ of the 443 MLD withdrawn would be above the defined salinity thresholds after 50 years under the baseline climate and land cover. In other words, 390 MLD would be below the thresholds and considered fresh, as compared to the 575 MLD in the optimized estimate. Under RCP 8.5 mid-century rainfall, 352 MLD of withdrawn water would be below the thresholds (compared to 481 MLD with optimization).

\section{Discussion}

Sustainable groundwater management requires an understanding of how future land-cover and climate change may affect groundwater yield and management. This is particularly the case on islands, like the Hawaiian Islands, where reliance on groundwater is high and options for groundwater substitutes are limited (Izuka et al. 1993; Holding et al. 2016). In Hawai'i and beyond there is strong interest by watershed managers and water regulators in understanding the role of watershed protection on groundwater management and costs, particularly in the broader context of other land-cover and climate change. While climate change (i.e. RCP 8.5 mid-century) is projected in this study to have approximately twice the impact of land-cover change, the results from this study demonstrate that informed land-cover planning, particularly watershed protection, can be an important climate change adaptation strategy. This supports general conclusions about the important, yet relatively smaller effect of land-cover versus climate change on groundwater that has been reported elsewhere (Candela et al. 2009; Van Roosmalen et al. 2009; Brewington et al. 2019).

In contrast to a similar study on the island of Maui (Brewington et al. 2019), which found an increase in overall recharge with future land-cover scenarios, the present study finds that all the land-cover scenarios decrease aggregate recharge compared to the baseline land-cover. The largest driver of this change is the potential invasion of native forest by high-water-use invasive species in the absence of protection activities (in the no-forest-protection scenario), but urban development also decreases recharge across most areas. Whereas Brewington et al. (2019) considered restoration of pasture in the fog zone, which increases recharge, the present study focuses only on the protection of native forest given a lack of high elevation grasslands available for restoration in the $\mathrm{Pu}$ 'uloa aquifer area, and stakeholder input that the costs of restoring existing nonnative forest are too high to be feasible.

\section{Benefits of native forest protection}

Holding urban development constant, sustainable yield and associated replacement costs among the three levels of native forest protection, suggest that forest protection can help to maintain sustainable yield and to partially mitigate the combined effects of land-cover change and a dry climate scenario. Results indicate that land-cover-induced changes in pumping are spatially variable, with the greatest benefits of forest protection in the Waipahu-Waiawa and Waimalu subaquifers, in line with previous work demonstrating that land cover can have important localized effects on groundwater even though the overall impact compared with climate may be relatively small (Dams et al. 2008). While the science around forest type and water use remains limited (Wright et al. 2018), this study utilizes the best available data to demonstrate the critical role that watershed partnerships and other source watershed protection efforts play in maintaining groundwater recharge, particularly in a context of current drying trends (Frazier and Giambelluca 2017). This study corroborates previous research on the economic value of watershed protection (Bremer et al. 2019; Wada et al. 2020), and also provides a more realistic evaluation of impacts on groundwater management and replacement costs through the linkage to a groundwater model and simulation optimization approach.

\section{Effects of urban development patterns}

Compared with watershed protection, urban development results in small changes in groundwater, with sprawl development reducing recharge and sustainable yield slightly more 
Fig. 9 a-l Change in land-cover, groundwater recharge ( $\mathrm{mm} /$ year), sustainable yield estimates displayed by pumping rates per well (MLD). All in comparison to baseline land-cover and under RCP 8.5 mid-century climate conditions and resulting optimized
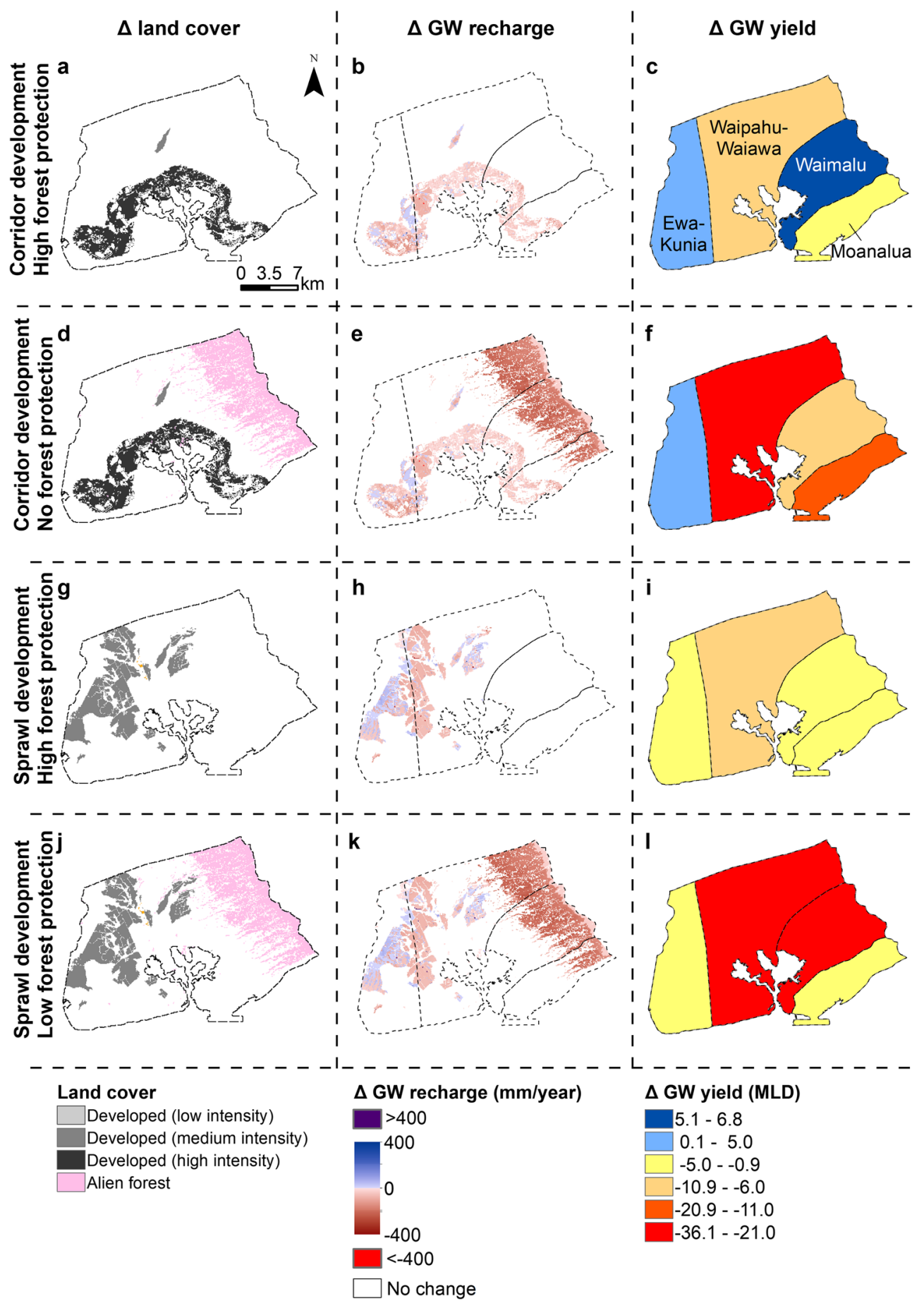

than corridor development. The relatively higher impact of forest protection versus urban development is, in part, due to the spatial location of urban development in the lower elevation, dry areas of the aquifer, whereas forest change occurs in the higher elevation, wet areas of the aquifer where recharge is greatest, and is thus most impacted. The main driver of reductions in recharge with development is a conversion of agriculture and a subsequent reduction in irrigation and pervious surfaces. In contrast, in the small, localized areas where development replaces nonnative forest or tree plantation, recharge increases. This demonstrates the importance of the initial land-cover type, the type of development, as well as environmental conditions in determining the impact of urban development (Han et al. 2017).

\section{Implications for current sustainable yield estimates}

Finally, this study also suggests that the current sustainable yield estimates set at 689 MLD using the Robust Analytical Model 2 (RAM 2) is likely a large overestimate. Under 
baseline land-cover and climate, the optimization simulation estimates sustainable yield as 575 MLD with land-cover and climate change further reducing this estimate. Compared with the spatial distribution of current pumping, optimization increases the amount of water that could be pumped below defined salinity thresholds. However, it is important to note that even the optimized sustainable yield for the baseline climate and land-cover (575 MLD) is lower than the RAM 2 estimate. This gap becomes even larger when considering land-cover and climate change, which further reduces sustainable yield as low as 428 MLD.

\section{Study limitations}

There are a number of important limitations of this study. First, there is substantial uncertainty regarding the climate and land-cover scenarios used, which are meant to represent a range of potential futures. This study uses the statistically downscaled dry climate scenario, RCP 8.5 mid-century. This scenario is $\sim 7 \%$ drier (due primarily to dry season anomalies) than the other available downscaled mid-century scenario for Hawai'i RCP 4.5 mid-century (Elison-Timm et al. 2014). However, dynamically downscaled climate data is also available for the end of century, which also projects overall drier conditions across the aquifer, but slightly wetter conditions in the highest elevation areas (Zhang et al. 2016). Future research could incorporate a greater range of climate projections into such analyses.

Second, there are limitations associated with the water balance model (Westenbroek et al. 2018; Mclean et al. 2019), including uncertainties around how forest types are parameterized given limited data on the ecohydrology of specific forest species and how this varies spatially under different conditions. The native and nonnative forest models are parameterized based on available water use rates of a typical native ('ōhi'a lehua; M. polymorpha) and typical nonnative (strawberry guava; $P$. cattleinanum) species. Uncertainties also exist in the PH SUTRA model regarding various hydrological and numerical aspects, which are described in Oki (2005). In addition, optimization results are subject to limitations as discussed by Elshall et al. (2015).

Finally, replacement cost calculations are based on projected water consumption, which will be partially dependent on other factors, including future water pricing and improvements in water efficiency. These costs will also hinge on the realized future cost of the next best alternative to groundwater, which is assumed here to be desalination, but will also shift over time in response to technological progress. In addition to further ecohydrological studies comparing native and nonnative forest types, there is also a need for further research into the outcomes of incorporating green roofs, rain gardens, and other green infrastructure approaches of urban development. As calibrated, the Hawai' $i$ SWB assumes less impervious surface with high-intensity development than low or medium-intensity development, but urban design approaches could increase the permeability of surfaces, slow down surface runoff, and increase recharge.

\section{Conclusions}

This study develops and applies a novel hydrologic ecosystem service valuation framework linking participatory development of land-cover scenarios with a spatially explicit groundwater optimization simulation and economic valuation, and applies it in the most heavily utilized aquifer in Hawai' $i$. Results point to the potential for watershed protection to help to mitigate the combined effects of land-cover and climate change on groundwater recharge, sustainable yield, and replacement costs. While a less important driver than reductions in rainfall from a dry climate scenario, forest protection is a far larger driver than trajectories of urban development, in part because of the location of urban development in drier areas. While the ecohydrology of various forest types is uncertain, the best available data suggests that native forest protection is an important supply side option that can help to adapt to the impacts of climate change. This is important information for water regulators, who set sustainable yield estimates, as well as for managers and potential funders of source watershed protection programs who seek to guide and justify management efforts. Additionally, this study demonstrates the value of combining participatory scenario development with hydrological and economic analyses for informing sustainable land and water management in Hawai' $i$ and other regions, particularly where species invasions threaten source watersheds.

Acknowledgements We thank Katie Ersbak (Department of Forestry and Wildlife) and Will Weaver (Ko'olau Watershed Partnership) for input on the forest conservation scenarios, and Leo Asunción (Hawai'i State Office of Planning) and the City and County of Honolulu for input into the development scenarios. We also gratefully acknowledge guidance from Gregory Chun from the University of Hawai' $i$, and Roy Hardy and Lenore Ohye from the Hawai'i Commission on Water Resource Management. We also thank Uli'i Miyajima, David Wade, and Scott Cloudwatcher, who provided technical assistance with scenario development. The simulation optimization method was developed with technical support from Delwyn Oki at USGS. The technical support and advanced computing resources from the University of Hawai' $i$ Information Technology Services - Cyberinfrastructure are gratefully acknowledged, especially David Schanzenback, Ron Merrill and Sean Cleveland. The data and simulation optimization codes developed for this study are available upon contacting the second author. This is contributed paper \# CP-2021-14 of the Water Resources Research Center at the University of Hawai'i at Mānoa.

Funding This research was funded in part by the National Science Foundation EPSCoR Grant No. OIA 1557349.

Open Access This article is licensed under a Creative Commons Attribution 4.0 International License, which permits use, sharing, adaptation, distribution and reproduction in any medium or format, as long as you give appropriate credit to the original author(s) and the source, 
provide a link to the Creative Commons licence, and indicate if changes were made. The images or other third party material in this article are included in the article's Creative Commons licence, unless indicated otherwise in a credit line to the material. If material is not included in the article's Creative Commons licence and your intended use is not permitted by statutory regulation or exceeds the permitted use, you will need to obtain permission directly from the copyright holder. To view a copy of this licence, visit http://creativecommons.org/licenses/by/4.0/.

\section{References}

Abell R, Asquith N, Boccaletti G, Bremer L, Chapin E, Erikson-Quiroz A, Higgins J, Johnson J, Kang S, Karres N, Lehner B, McDonald R, Raepple J, Shemie D, Simmons E, Sidhar A, Vigerstol K, Vogl A, Wood S (2017) Beyond the source: the environmental, economic and community benefits of source water protection. The Nature Conservancy, Arlington, VA

Bierkens MFP, Wada Y (2019) Non-renewable groundwater use and groundwater depletion: a review. Environ Res Lett 14:063002. https://doi.org/10.1088/1748-9326/ab1a5f

Brauman KA (2015) Hydrologic ecosystem services: linking ecohydrologic processes to human well-being in water research and watershed management. WIREs Water 2:345-358. https://doi. org/10.1002/wat2.1081

Brauman KA, Freyberg DL, Daily GC (2015) Impacts of land-use change on groundwater supply: ecosystem services assessment in Kona, Hawaii. J Water Resour Plan Manag 141:1-11. https://doi.org/10. 1061/(ASCE)WR.1943-5452.0000495

Brauman KA, Benner R, Benitez S, Bremer L, Vigerstol K (2019) Water Funds. In: Mandle L, Ouyang Z, Salzman JE, Daily G (eds) Green growth that works: natural capital policy and finance mechanisms from around the world. Center for Resource Economics, Washington, DC, pp 118-140

Bremer LL, Delevaux JMS, Leary JJK, Cox LJ, Oleson KL (2015) Opportunities and strategies to incorporate ecosystem services knowledge and decision support tools into planning and decision making in Hawai' i. Environ Manag 55. https://doi.org/10.1007/s00267-014-0426-4

Bremer LL, Wada CA, Medoff S, Falinski K, Burnett KM (2019) Contributions of native forest protection to local water supplies in East Maui. Sci Total Environ 688:1422-1432. https://doi.org/10. 1016/j.scitotenv.2019.06.220

Bremer LL, Hamel P, Ponette-González AG, Pompeu PV, Saad SI, Brauman KA (2020) Who are we measuring and modeling for? Supporting multilevel decision-making in watershed management. Water Resour Res 56:1-17. https://doi.org/10.1029/ 2019WR026011

Brewington L, Keener V, Mair A (2019) Simulating land-cover change impacts on groundwater recharge for. Remote Sens 11:3048. https:// doi.org/10.3390/rs 11243048

Brewington L, Bremer LL, Elshall AS (2020) Data of Effects of land 696 cover and watershed protection futures on sustainable groundwater management in 697 Hawai $^{\circ} \mathrm{i}$ (Version v1.0). Zenodo. https://doi.org/ 10.5281/zenodo.3930544

Burnett K, Wada C, Balderston A (2017) Benefit-cost analysis of watershed conservation on Hawai'i Island. Ecol Econ 131:262-274. https://doi.org/10.1016/j.ecolecon.2016.09.013

Burnett K, Wada CA (2014) Optimal groundwater management when recharge is declining: a method for valuing the recharge benefits of watershed conservation. Environmental Economics and Policy Studies 16 (3):263-278

Burnett KM, Elshall AS, Wada CA, Arik A, El-Kadi AI, Delevaux JMS, Bremer LL (2020) Incorporating historical spring discharge protection into sustainable groundwater management: a case study from Pearl Harbor aquifer, Hawai'i. Front Water 2:14. https://doi. org/10.3389/frwa.2020.00014

Calthorpe Associates (2013) Honolulu Transit Oriented Development Study scenarios. https:/www.calthorpe.com/sites/default/files/ Honolulu\%20TOD\%20Scenarios\%20Report.pdf. Accessed February 2021

Candela L, Von Igel W, Javier Elorza F, Aronica G (2009) Impact assessment of combined climate and management scenarios on groundwater resources and associated wetland (Majorca, Spain). J Hydrol 376:510-527. https://doi.org/10.1016/j.jhydrol.2009.07.057

Cavaleri MA, Ostertag R, Cordell S, Sack L (2014) Native trees show conservative water use relative to invasive trees: results from a removal experiment in a Hawaiian wet forest. Conserv Physiol 2:114. https://doi.org/10.1093/conphys/cou016

Chun G, Adler P, Arik AD, Burnett KM, Redding N, Wada CA (2017) Organizational Study of Water Management Networks and Processes in Hawai'i. Study conducted and prepared for the Ulupono Initiative, Honolulu, Hawai' $\mathrm{i}$

Cross K, Laban P, Paden M, Smith M (2016) Spring: managing groundwater sustainability. IUCN Global Water Programme. https://doi. org/10.2305/IUCN.CH.2016.WANI.8.en

Dams J, Woldeamlak ST, Batelaan O (2008) Predicting land-use change and its impact on the groundwater system of the Kleine Nete catchment, Belgium. Hydrol Earth Syst Sci 12:1369-1385. https://doi. org/10.5194/hess-12-1369-2008

Dawes W, Ali R, Varma S, Emelyanova I, Hodgson G, McFarlane D (2012) Modelling the effects of climate and land-cover change on groundwater recharge in south-west Western Australia. Hydrol Earth Syst Sci 16:2709-2722. https://doi.org/10.5194/hess-162709-2012

Elison Timm O, Giambelluca TW, Diaz HF (2014) Statistical downscaling of rainfall changes in Hawai' $i$ based on the CMIP5 global model projections. J Geophys Res Atmos 92-112. https://doi.org/10.1002/ 2014JD022059

Elshall AS, Pham H, Tsai FT-C, Yan L, Ye M (2015) Parallel inverse modeling and uncertainty quantification of computationally demanding groundwater flow models using covariance matrix adaptation. J Hydrol Eng 20(8):04014087. https://doi.org/10.1061/(ASCE) HE.1943-5584.0001126

Elshall AS, Arik AD, El-Kadi AI, Pierce S, Ye M, Burnett KB, Wada CA, Bremer LL, Chun G (2020) Groundwater sustainability: a review of the interactions between science and policy. Environ Res Lett. https://doi.org/10.1088/1748-9326/ab8e8c

Engott JA (2011) A water-budget model and assessment of groundwater recharge for the Island of Hawai'i. US Geol Surv Sci Invest Rep 2011-5078. https://pubs.usgs.gov/sir/2011/5078/. Accessed February 2021

Engott JA, Johnson AG, Bassiouni M, Ikuka SK, Rotzoll K (2017) Spatially distributed groundwater recharge for 2010 land-cover estimated using a water-budget model for the Island of $\mathrm{O}^{`}$ ahu, Hawai' $\mathrm{i}$ (ver. 2.0, December 2017). US Geol Surv Sci Invest Rep 20155010. https://doi.org/10.3133/sir20155010

Frazier AG, Giambelluca TW (2017) Spatial trend analysis of Hawaiian rainfall from 1920 to 2012. Int J Climatol 37:2522-2531. https://doi. org/10.1002/joc.4862

Geometrician Associates (2010) Draft environmental assessment: biocontrol of strawberry guava by its natural control agent for preservation of native forests in the Hawaiian Islands. Prepared for the State of Hawai'i Department of Land and Natural Resources. http://oeqc2.doh.hawaii.gov/EA_EIS_Library/2010-06-23-STDEA-Biocontrol-Strawberry-Guava.pdf. Accessed February 2021

Giambelluca TW, Delay JK, Asner GP, Martin RE, Nullet MA, Mudd RG, Huang M, Takahshi M (2008) Stand structural controls on evapotranspiration in native and invaded tropical Montane Cloud 
Forest in Hawai'i. American Geophysical Union, Fall Meeting 2008, B43A-0422, AGU, Washington, DC

Giambelluca TW, Chen Q, Frazier AG, Price JP, Yi-Leng C, Chu P, Eischeid JK, Delparte DM (2013) Online rainfall atlas of Hawai'i. Bull Am Meteor Soc 94:313-316. https://doi.org/10.1175/BAMSD-11-00228.1

Giambelluca TW, Shuai X, Barnes ML, Alliss RJ (2014) Evapotranspiration of Hawai' $\mathrm{i}$ final report. http:// evapotranspiration.geography.hawaii.edu/assets/files/PDF/ET\% 20Project\%20Final\%20Report.pdf. Accessed February 2021

Giordano M (2009) Global groundwater issues and solutions. Annu Rev Environ Resour 34:153-178. https://doi.org/10.1146/annurev. environ.030308.100251

Gleeson T, Alley WM, Allen DM, Sophocleous MA, Zhou Y, Taniguchi M, VanderSteen J (2012) Towards sustainable groundwater use: setting long-term goals, backcasting, and managing adaptively. Ground Water 50:19-26. https://doi.org/10.1111/j.1745-6584. 2011.00825.x

Gleeson T, Cuthbert M, Ferguson G, Perrone D (2020) Global groundwater sustainability, resources, and systems in the Anthropocene. Annu Rev Earth Planet Sci 48:431-463. https://doi.org/10.1146/ annurev-earth-071719-055251

Guswa A, Brauman K, Brown C, Hamel P, Keeler BL, Stratton SS (2014) Ecosystem services: Challenges and opportunities for hydrologic modeling to support decision making. Water Resour Res 1-10. https://doi.org/10.1002/2014WR015497.Received

Hamel P, Riveros-Iregui D, Ballari D, Browning T, Célleri R, Chandler D, Chun KP, Destouni G, Jacobs JS, Johnson M, Krishnaswamy J, Poca M, Pompeu PV, Rocha H (2017) Watershed services in the humid tropics: opportunities from recent advances in ecohydrology. Ecohydrology 11:e1921. https://doi.org/10.1002/eco.1921

Han D, Currell MJ, Cao G, Hall B (2017) Alterations to groundwater recharge due to anthropogenic landscape change. J Hydrol 554:545557. https://doi.org/10.1016/j.jhydrol.2017.09.018

Hansen JK (2012) The economics of optimal urban groundwater management in southwestern USA. Hydrogeol J 20:865-877. https:// doi.org/10.1007/s10040-012-0841-7

Hansen N, Müller SD, Koumoutsakos P (2003) Reducing the time complexity of the derandomized evolution strategy with covariance matrix adaptation (CMA-ES). Evolutionary computation 11(1):1-18

Holding S, Allen DM, Foster S, Hsieh A, Larocque I, Klassen J, Van Pelt SC (2016) Groundwater vulnerability on small islands. Nat Clim Chang 6:1100-1103. https://doi.org/10.1038/nclimate3128

Honolulu Board of Water Supply (2016) Water Master Plan. Prepared by CDM Smith

Izuka SK, Hill B, Shade PJ, Tribble GW (1993) Geohydrology and possible transport routes of polychlorinated biphenyls in Haiku Valley, Oahu, Hawaii. US Geol Surv Water Resour Invest Rep 92-4168. https://doi.org/10.3133/wri924168

Izuka SK, Engott JA, Rotzoll K, Bassiouni M, Johnson AG, Miller LD, Mair A (2018) Volcanic Aquifers of Hawai'i: Hydrogeologywater budgets, and conceptual models. US Geol Surv Water Resour Invest Rep 2015-5164. https://doi.org/10.3133/sir20155164

James Roumasset, Christopher A. Wada, (2015) Payments for Watershed Services as Adaptation to Climate Change: Upstream Conservation and Downstream Aquifer Management. Water Economics and Policy 01 (01):1450003

Johnson A, Engott JA, Bassiouni M (2014) Spatially distributed groundwater recharge estimated using a water-budget model for the Island of Maui, Hawai'i, 1978-2007. US Geol Surv Water Resour Invest Rep 2014-5168. https://doi.org/10.3133/sir20145168

Kagawa A, Sack L, Duarte K, James S (2009) Hawaiian native forest conserves water relative to timber plantation: species and stand traits influence water use. Ecol Appl 19:1429-1443. https://doi.org/10. 1890/08-1704.1
Keeler BL, Polasky S (2014) Land-use change and costs to rural households: a case study in groundwater nitrate contamination. Environ Res Lett 9:. https://doi.org/10.1088/1748-9326/9/7/074002

Kløve B, Ala-Aho P, Bertrand G, Gurdak JK, Kupfersberger H, Kvaerner J, Muotka T, Mykra H, Preda E, Rossi P, Uvo CB, Velasco E, Pulido Valezquez M (2014) Climate change impacts on groundwater and dependent ecosystems. J Hydrol 518:250-266. https://doi. org/10.1016/j.jhydrol.2013.06.037

Konikow LF, Kendy E (2005) Groundwater depletion: a global problem. Hydrogeol J 13:317-320. https://doi.org/10.1007/s10040-0040411-8

Kroeger T, Klemz C, Boucher T, Fisher JRB, Acosta E, Targa Cavassani A, Dennedy-Frank PJ, Garbossa L, Balinski E, Comparim Santos R, Giberti S, Petry P, Shemie D, Dacol K (2019) Returns on investment in watershed conservation: application of a best practices analytical framework to the Rio Camboriú Water Producer program, Santa Catarina, Brazil. Sci Total Environ 657:1368-1381. https://doi.org/ 10.1016/j.scitotenv.2018.12.116

LANDFIRE (2012) Existing Vegetation Type Layer, LANDFIRE 1.3.0. US Geological Survey, Reston, VA

Liu CCK (2006) Analytical groundwater flow and transport modeling for the estimation of the sustainable yield of Pearl Harbor aquifer. WRRC project report 2006-06, Water Resources Research Center, University of Hawai'i at Mānoa, Honolulu, Hawai'i

Maui County Department of Water Supply (2019) Maui Island Water Use and Development Plan Draft

McLean, JH, Rotzoll K., Cleveland SB, Izuka, SK (2019a) The Hawai'i Groundwater Recharge Tool: website at https://recharge.ikewai.org.

McLean JH, Cleveland SB, Rotzoll K, Izuka SK, Leigh J, Jacobs GJ, Theriot R (2019b). The 'Ike Wai Hawai'i Groundwater Recharge Tool. Proc. Gateways, San Diego, CA, USA, September 2019. https://doi.org/10.17605/OSF.IO/TH9W2.

Melrose J, Perroy R, Cares S (2016) Statewide Agricultural Land Use Baseline 2015. Hawai'i Department of Agriculture, Hilo. http:// hdoa.hawaii.gov/salub/

Miles A (2020) If we get food right, we get everything right: rethinking the food system in post-COVID-19 Hawai'i. Civil Beat, 11 April 2020

Mink JF (1980) State of the Groundwater Resources of Southern Oahu. Board of Water Supply, City and County of Honolulu, Hawai'i. http://hdl.handle.net/10125/50765. Accessed February 2021

Mink J (1981) Determination of sustainable yields in basal aquifers of Hawai'i. In: Groundwater in Hawai'i: a century of Progress. Water Resources Research Center, University of Hawai'i at Mānoa, Honolulu, Hawai'i, pp 101-116

Mohan C, Western AW, Wei Y, Saft M (2018) Predicting groundwater recharge for varying land-cover and climate conditions: a global meta-study. Hydrol Earth Syst Sci 22:2689-2703. https://doi.org/ 10.5194/hess-22-2689-2018

Moosdorf N, Oehler T (2017) Societal use of fresh submarine groundwater discharge: an overlooked water resource. Earth-Science Rev 171: 338-348. https://doi.org/10.1016/j.earscirev.2017.06.006

Narasimhan TN (2009) Groundwater: from mystery to management. Environ Res Lett 4:. https://doi.org/10.1088/1748-9326/4/3/035002

Oki DS (2005) Numerical simulation of the effects of low-permeability valley-fill barriers and the redistribution of ground-water withdrawals in the Pearl Harbor area, Oahu, Hawaii. US Geol Surv Sci Invest Rep 2005-5253. https://doi.org/10.3133/sir20055253

Ozment S, Feltran-Barbieri R, Hamel P, Gray E, Ribeiro JB, Barreto SR, Padovezi A, Valente PT (2018) Natural Infrastructure in São Paulo's Water System. Water Resources Institute. https://www.wri.org/ publication/natural-infrastructure-sao-paulo. Accessed February 2021

Perroy RL, Melrose J, Cares S (2016) The evolving agricultural landscape of post-plantation Hawai 'i. Applied Geography 76:154-162 
Pierce SA, Sharp JM, Guillaume JHA, Mace RE, Eaton DJ (2013) Aquifer-yield continuum as a guide and topology for sciencebased groundwater management. Hydrogeol J 21:331-340. https:// doi.org/10.1007/s10040-012-0910-y

Poelmans L, Van Rompaey A, Batelaan O (2010) Coupling urban expansion models and hydrological models: how important are spatial patterns? Land Use Policy 27:965-975. https://doi.org/10.1016/j. landusepol.2009.12.010

Povak NA, Hessburg PF, Giardina CP, Reynolds KM, Heider C, Salminen E, Salter RB, MacKenzie RA (2017) A watershed decision support tool for managing invasive species on Hawai' $i$ Island, USA. For Ecol Manag 400:300-320. https://doi.org/10.1016/j. foreco.2017.05.046

Pulido-Velazquez M, Peña-Haro S, García-Prats A, Mocholi-Almudever AF, Henriquez-Dole L, Sorribes-Macian H, Lopez-Nicolas A (2015) Integrated assessment of the impact of climate and land use changes on groundwater quantity and quality in the Mancha oriental system (Spain). Hydrol Earth Syst Sci 19:1677-1693. https://doi. org/10.5194/hess-19-1677-2015

Roumasset J, Wada CA (2015) Payments for watershed services as adaptation to climate change: upstream conservation and downstream aquifer management. Water Econ Pol 1(01), 1450003.

Rudestam K, Langridge R (2014) Sustainable yield in theory and practice: bridging scientific and mainstream vernacular. Ground Water 52:90-99. https://doi.org/10.1111/gwat.12160

Salzman J, Bennett G, Carroll N, Goldstein A, Jenkins M (2018) The global status and trends of payments for ecosystem services. Nat Sustain 1:136-144. https://doi.org/10.1038/s41893-018-0033-0

Sanford T, Frumhoff PC, Luers A, Gulledge J (2014) The climate policy narrative for a dangerously warming world. Nat Clim Chang 4:164 166. https://doi.org/10.1038/nclimate2148

Schwalm CR, Glendon S, Duffy PB (2020) RCP8.5 tracks cumulative $\mathrm{CO}_{2}$ emissions. Proc Natl Acad Sci 117:19656-19657. https://doi. org/10.1073/pnas.2007117117

State of Hawai'i (2019) State land use districts. State of Hawai' $i$ Office of Planning, Honolulu, Hawai'i. https://www.arcgis.com/sharing/rest/ content/items/7b6e118ffe5d4370923dde14ed1 ea6e3/info/metadata/ metadata.xml?format=default\&output=html . Accessed March 2019

State of Hawai'i (2019) Important agricultural lands. State of Hawai' $i$, Land Use Commission, Honolulu, HI

Taylor RG, Scanlon B, Döll P, Rodell M, van Beek R, Wada Y, Longuevergne L, Leblanc M, Famigletti JS, Edmunds M, Konikow L, Green TR, Chen J, Taniguchi M, Bierkens MFP, MacDonald A, Fan, Y, Maxwell RM, Yechieli Y, Gurdak JJ, Allen DM, Shamsudduha M, Hiscock K, Yeh PJF, Holman I, Treidel H (2013) Ground water and climate change. Nat Clim Chang 3:322-329. https://doi.org/10.1038/nclimate1744

Thornthwaite CW, Mather JR (1955) The water balance. Publ Climatol 8: 1850311
Thornthwaite CW, Mather (1957) Instructions and tables for computing potential evapotranspiration and the water balance. Publ Climatol $10: 1-104$

Townscape (2019) Hawai'i Water Plan: water resource protection plan 2019 update. Prepared for the State of Hawai'i Commission on Water Resources Management, Honolulu, HI. https://files.hawaii. gov/dlnr/cwrm/planning/wrpp2019update/WRPP_201907.pdf. Accessed February 2021

Tribble G (2008) Ground water on tropical pacific islands-understanding a vital resource. US Geol Surv Circ 1312. https://doi.org/10.3133/ cir1312. Accessed February 2021

Van Roosmalen L, Sonnenborg TO, Jensen KH (2009) Impact of climate and land use change on the hydrology of a large-scale agricultural catchment. Water Resour Res 45:1-18. https://doi.org/10.1029/ 2007WR006760

Voss CI, Provost A (2002) SUTRA: a model saturated-unsaturated variable-density ground-water flow with solute or energy transport. https://www.usgs.gov/software/sutra-a-model-2d-or-3d-saturatedunsaturated-variable-density-ground-water-flow-solute-or. Accessed February 2021

Wada CA, Bremer LL, Burnett K, Trauernicht C, Giambelluca T, Mandle L, Parsons E, Wiel C, Kurashima K, Ticktin T (2017) Estimating cost-effectiveness of Hawaiian dry forest restoration using spatial changes in water yield and landscape flammability under climate change. Pacific Sci 71. https://doi.org/10.2984/71.4.2

Wada CA, Pongkijvorasin S, Burnett KM (2020) Mountain-to-sea ecological-resource management: forested watersheds, coastal aquifers, and groundwater dependent ecosystems. Resour Energy Econ 59:101146. https://doi.org/10.1016/j.reseneeco.2019.101146

Westenbroek S, Engott J, Keson V, Hunt R (2018) SWB Version 2.0: a soil-water-balance code for estimating net infiltration and other water-budget components. US Geological Survey Techniques and Methods, book 6, chapt. A59, US Geological Survy, Reston, VA, $118 \mathrm{pp}$

Wheater HS, Gober P (2015) Water security and the science agenda. Water Resour Res 51:5406-5424. https://doi.org/10.1002/ 2015WR017200.A

Wilcox C (1996) Sugar water: Hawai'i's plantation ditches. University of Hawai'i Press, Honolulu, HI

Wright C, Kagawa-Viviani A, Gerlein-Safdi C, Mosquera GM, Poca M, Tseng H, Chun KP (2018) Advancing ecohydrology in the changing tropics: perspectives from early career scientists. Ecohydrology 11(3). https://doi.org/10.1002/eco.1918

Zhang C, Wang Y, Hamilton K, Lauer A (2016) Dynamical downscaling of the climate for the Hawaiian islands, part II: projection for the late twenty-first century. J Clim 29:8333-8354. https://doi.org/10.1175/ JCLI-D-16-0038.1

Publisher's note Springer Nature remains neutral with regard to jurisdictional claims in published maps and institutional affiliations. 